\title{
Post-embryonic larval development and metamorphosis of the hydroid Eudendrium racemosum (Cavolini) (Hydrozoa, Cnidaria)
}

\author{
C. Sommer \\ Lehrstuhl für Spezielle Zoologie und Parasitologie, \\ Ruhr-Universität Bochum; D-W-4630 Bochum, Germany
}

\begin{abstract}
The morphology and histology of the planula larva of Eudendrium racemosum (Cavolini) and its metamorphosis into the primary polyp are described from light microscopic observations. The planula hatches as a differentiated gastrula. During the lecithotrophic larval period, large ectodermal mucous cells, embedded between epitheliomuscular cells, secrete a sticky slime. Two granulated cell types occur in the ectoderm that are interpreted as secretory and sensorynervous cells, but might also be representatives of only one cell type with a multiple function. The entoderm consists of yolk-storing gastrodermal cells, digestive gland cells, interstitial cells, cnidoblasts, and premature cnidocytes. The larva starts metamorphosis by affixing its blunt aboral pole to a substratum. While the planula flattens down, the mucous cells penetrate the mesolamella and migrate through the entoderm into the gastral cavity where they are lysed. Subsequently, interstitial cells, cnidoblasts, and premature cnidocytes migrate in the opposite direction, i.e. from entoderm to ectoderm. Then, the polypoid body organization, comprising head (hydranth), stem and foot, all covered by peridermal secretion, becomes recognisable. An oral constriction divides the hypostomal portion of the gastral cavity from the stomachic portion. Within the hypostomal entoderm, cells containing secretory granules differentiate. Following growth and the multiplication of tentacles, the head periderm disappears. A ring of gland cells differentiates at the hydranth's base. The positioning of cnidae in the tentacle ectoderm, penetration of the mouth opening and the multiplication of digestive gland cells enable the polyp to change from lecithotrophic to planktotrophic nutrition.
\end{abstract}

\section{INTRODUCTION}

Life cycle in the Eudendriidae comprises the typical cnidarian larva, the planula, which metamorphoses into a primary polyp that by asexual reproduction gives origin to a monopodially-growing colony (Kühn, 1913; Mergner, 1957). Due to complete suppression of the medusa generation in all members of the family, gonadial tissue is borne on specialized male and female hydranths, named blastostyles. The source and maturation of oocytes as well as the embryonic development of planulae were thoroughly analysed by Mergner (1957) in Eudendrium racemosum and by Wasserthal (1973) in E. armatum. Hanisch $(1966,1970)$ investigated spermatogenesis in E. racemosum.

In contrast, the post-embryonic period, including larval development, settlement, and metamorphosis, has still received little attention. Some information on the larval biology of $E$. armatum, E. rameum, and $E$. racemosum, especially concerning the vivid mucus secretion of floating planulae and its ecological importance, was given by 
Wasserthal \& Wasserthal (1973). The only histological description of metamorphosis in the Eudendriidae is a brief note on E. racemosum published by Mergner (1971) as part of a general survey on developmental biology in the Cnidaria. He reported the disappearance of mucous and sensory-nervous cells from the ectoderm and the migration of interstitial cells, cnidoblasts, and premature cnidocytes from entodermal to ectodermal germ layer shortly after the onset of metamorphosis.

Histological data on larvae and their metamorphosis are available from several other hydroid families, e.g. Clavidae (Morgenstern, 1901; Harm, 1903; van de Vyver, 1967), Hydractiniidae (van de Vyver, 1964, 1967; Bodo \& Bouillon, 1968; Weis et al., 1985; Weis \& Buss, 1987), Corynidae (van de Vyver, 1967; Bodo \& Bouillon, 1968), Halocordylidae (Hargitt, 1900; Martin \& Thomas, 1977, 1980, 1981a, b; Hotchkiss et al., 1984; Martin \& Archer, 1986a, b), and Mitrocomidae (Martin et al., 1983). They indicate a mixture of both constant and variable developmental patterns between different families, revealing hydroid metamorphosis as a profitable field for comparative developmental studies.

\section{MATERIAL AND METHODS}

Female colonies of Eudendrium racemosum (Cavolini) bearing numerous developing embryos were collected during August/September 1986 by SCUBA- or skin-diving along the coast of the Portofino Peninsula, about $30 \mathrm{~km}$ southeast of Genoa, Italy, at depths from 0.5 to $25 \mathrm{~m}$. The colonies were kept for up to two weeks at $22-26^{\circ} \mathrm{C}$ in round plastic bowls containing daily-changed, filtered sea water (ca $2 \mathrm{~cm}$ depth), without feeding or aeration. Hatched planulae were harvested twice a day and transferred with a pipette to petri dishes. Larval settlement and metamorphosis were easily induced by adding pieces of marine algae such as Ulva lactuca and Enteromorpha sp. or other natural substrata taken from the sea. Free planulae or specimens at selected stages of metamorphosis were fixed in Bouin's fluid, $4 \%$ formaldehyde, or picro-formol (after Jha, 1965), at room temperature overnight, and then transferred to $70 \%$ ethanol. Following dehydration they were embedded in Paraplast-Plus, cut to $5 \mu \mathrm{m}$ sections and stained with azan (after Heidenhain), azure II - eosine (after Nocht-Maximow), Giemsa's solution, iron hematoxyline (after Weigert or Heidenhain), or acid hemalum (after P. Mayer or Ehrlich) (details after Romeis, 1968, and Burck, 1973). The best results were obtained with azan. This stain was sometimes combined with alcian blue $8 \mathrm{GS}$, a selective dye for acid mucopolysaccharides (Chayen et al., 1975).

The histological illustrations were drawn with the aid of a drawing tube (Leitz) mounted on a Leitz-Dialux light microscope, using bright field and phase-contrast equipment alternately.

\section{RESULTS}

\section{Hatching of planulae}

At the time of hatching, the larva has already attained the diploblastic body organization peculiar to all Cnidaria, comprising an inner entoderm (Fig. 1; ent) and an outer ectoderm (ect), separated by a thin, acellular sheet, the mesolamella (mes).

A peridermal envelope (Fig. 1 ; pe) surrounds the embryo from an early stage of development (cf. Mergner, 1957), and hatching is initiated by a striking decrease in its 


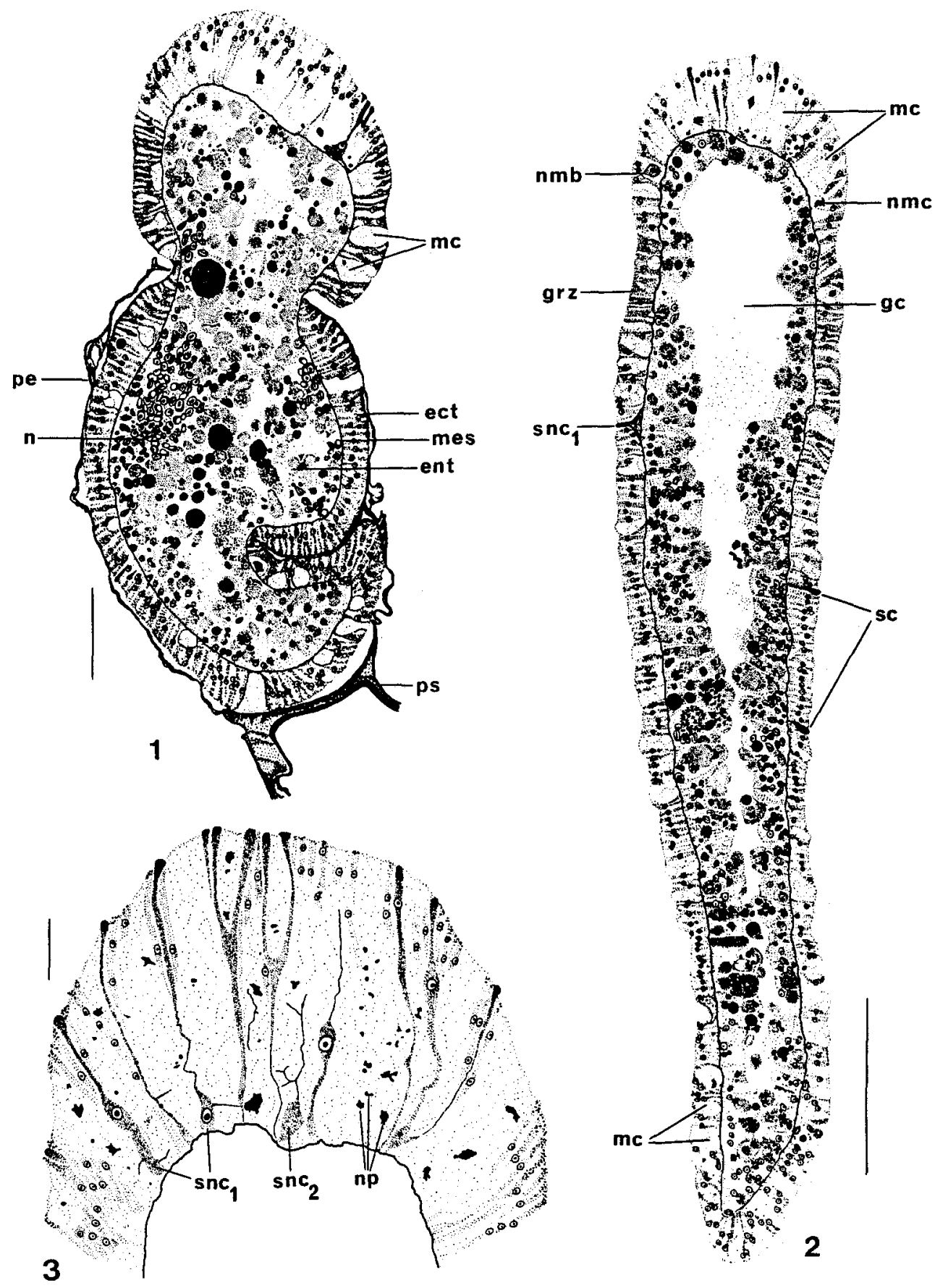

Figs 1-3. Eudendrium racemosum. 1. Hatching planula; 2. Post-hatching larva; 3. Aboral pole of a planula (only ectodermal layer drawn). Scales: Fig. 1:50 $\mu$; Fig. 2: $100 \mu \mathrm{m}$; Fig. 3: $15 \mu \mathrm{m}$ 
thickness. This process culminates locally in the formation of a circular opening at the animal pole of the egg capsule, which corresponds in position with the aboral pole of the planula. At the opposite pole the egg is fastened to the female blastostyle by a thick and multilayered periderm socle (Fig. 1; ps).

Planulae always hatch by leaving the egg aboral pole first. Then they slowly wind

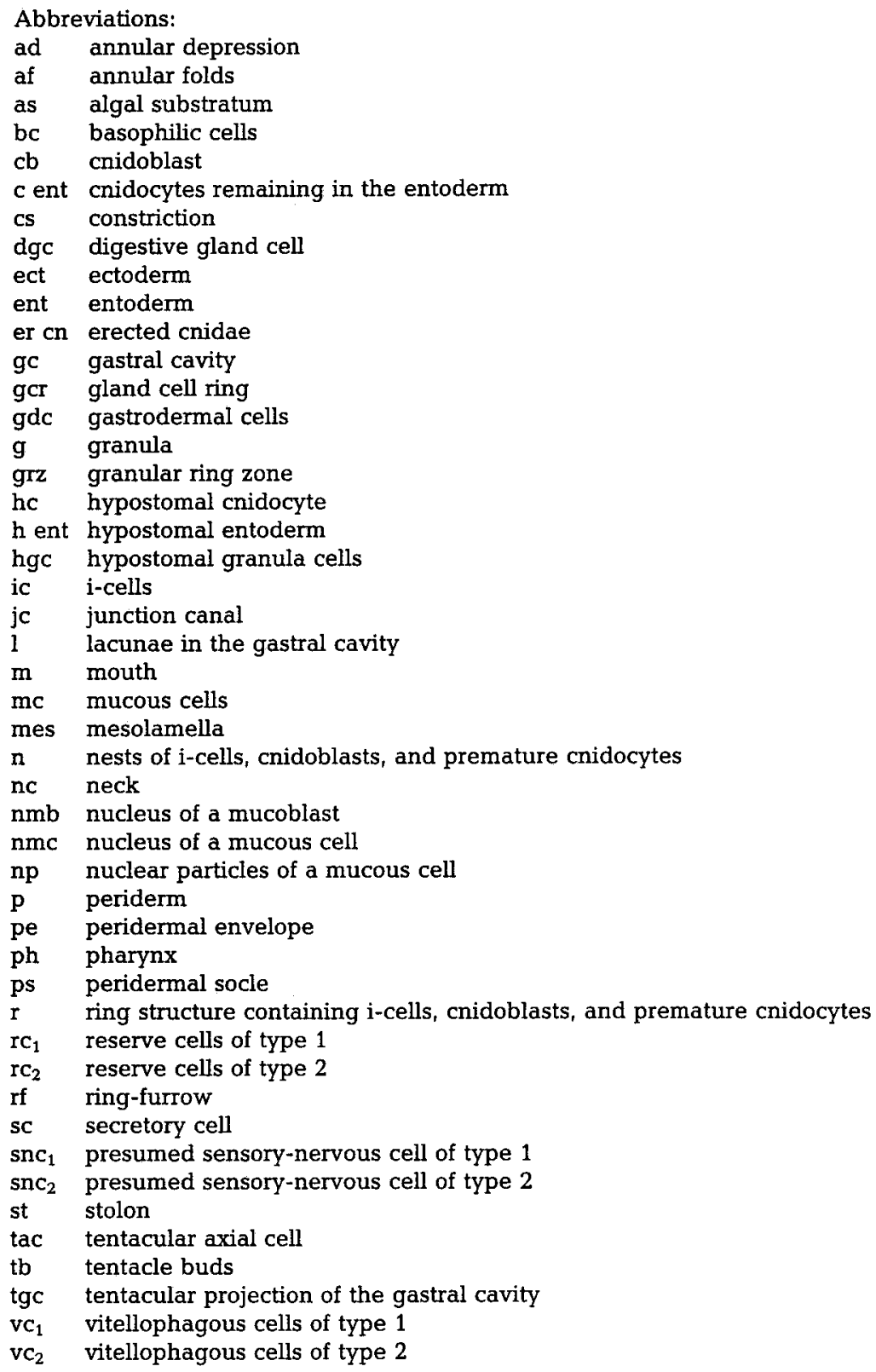


the hind part of their body through the opening in the egg membrane. Especially the ectoderm of the larva becomes highly constricted as it passes through the narrow opening (Fig. 1).

The most prominent elements in the ectoderm besides epitheliomuscular cells are mucous cells (Fig. $1_{i} \mathrm{mc}$ ). They are mainly concentrated towards the aboral pole. Cells of this type are swollen, often vase- or bottle-shaped and filled with an amorphous, lowrefringent, alcianophilic material. Observations on living animals demonstrated that mucus secretion begins intensively even during the course of hatching. Thus, after leaving the egg, the larvae stay in contact with the empty capsule for some time, still attached by a slowly prolonging, sticky slime rope that extends from the oral pole of the planula to the surface of the egg capsule. This behaviour, termed "roping down", has been described in E. armatum, E. rameum, and E. racemosum (Wasserthal \& Wasserthal, 1973).

A characteristic feature of the entoderm is the high density of stored yolk particles. After staining with azan, several types of yolk can be distinguished: (1) deep blue particles of irregular shape; (2) a pale blue, probably more "liquid" mass not lying within the gastrodermal cells but free in the developing gastral cavity; (3) blue particles similar to those described under (1), but containing lots of red granules of differing grades of density, and (4) pure red particles which are always spherical, but of varied sizes. Except for type 2, yolk is normally enclosed in large gastrodermal cells which contain only small amounts of cytoplasm.

In addition to yolk, the inner germ layer contains great numbers of non-differentiated interstitial cells (i-cells) together with cnidoblasts and premature cnidocytes. These are concentrated in the mid-gastric region of the planula, most of them lying as clustered nests near the mesolamella (Fig. 1; n). Digestive gland cells are rarely found (Fig. 5).

\section{Free planulae}

Newly-hatched planulae are worm-shaped and about $0.6-0.7 \mathrm{~mm}$ long. The aboral pole is blunt and the oral pole is tapered. After hatching, the body elongates and may reach a length of $1.3-1.6 \mathrm{~mm}$ after one day. Free planulae are not able to swim actively but float passively for some time, being distributed by currents. When eventually they adhere to a substratum with the help of secreted mucus, the larvae glide forward with the aboral pole ahead. This movement is coupled with a slow anti-clockwise rotation of the body. At the same time, a planula leaves a slime trail behind similar to that of a snail. The forward-movement is produced by the beating of ectodermal cilia.

The cellular composition of the germ layers does not alter after hatching. Ectodermal epitheliomuscular cells are cylindrical, with their nuclei being normally located in the middle or apical region. Shortly behind the aboral pole, the epitheliomuscular cells possess a conspicuous apical granulation that forms a granular ring zone around the larval body (Fig. 2; grz). In all planulae, mucous cells are concentrated at the aboral pole and, to a lesser extent, at the tapered oral pole, but are also sparsely scattered over the whole body (Fig. 2; mc).

Certain findings possibly indicate that the nuclei of older mucous cells degenerate by fragmentation. Nuclei of younger cells (mucoblasts) are approximately spherical to ellipsoid with diameters of about 8-10 $\mu \mathrm{m}$, and possess a single, great nucleolus (Fig. 2; 
nmb). Maturation of the cells is accompanied by the condensation of chromatine, while the shape of the nucleus becomes irregular due to the formation of protruding spines and hooks (Fig. 2; nmc). Subsequently, some of the protrusions apparently break off and are randomly dispersed in the surrounding mucus. Fragmentation is continued until the nucleus is totally degraded into small particles (Fig. 3; np), the fate of which cannot be followed. Synchronously with nuclear degeneration, the amount of cytoplasm is more and more diminished and replaced by mucus.

Two other ectodermal cell types are present in hatching as well as in free planulae. They resemble each other in containing densely-packed, acidophilic granules and can be distinguished only on the basis of cell morphology. The first type is similar to epitheliomuscular cells in being long and cylindrical (Fig. 2; sc). Wasserthal \& Wasserthal (1973) described cells like these from mature planulae of $E$. armatum and supposed them to be secretory in function ("kleine sekretorische Zellen", i.e. small secretory cells). The second cell type differs from the first in having one or two long plasma processes running from the cell's basal region between the intercellular spaces of neighbouring epitheliomuscular cells (Figs 2, 3, 4; snc $_{1}$ ). Others project a very delicate fibre apicad that can ramify several times and probably ends free in the epithelium (Fig. 3 ; snc $_{2}$ ). Similar cells have been well described and illustrated in the embryological study of Mergner (1957) and were named "Sinnesnervenzellen" (i.e. sensory-nervous cells) to stress their presumed dual function of stimulus perception and conduction.

The entodermal epithelium of a post-hatching planula centrally borders a lengthwise extending gastral cavity (Fig. 2; gc). It widens near the aboral pole and narrows at the oral one. The absence of a mouth and the presence of numerous yolk particles stored within the low-columnar gastrodermal cells show the larva to be lecithotrophic.

In the majority of post-hatching planulae, the entodermal nests of i-cells, cnidoblasts, and premature cnidocytes are not so concentrated as in hatching ones, perhaps due to the longitudinal extension of the planula body (see above). A few i-cells and premature cnidocytes penetrate the mesolamella and move into the ectoderm. However, no cnidae are arranged in a position for discharge between the epitheliomuscular cells. Based upon the typical stylet apparatus, all cnidocysts detected in both germ layers can be classified as microbasic euryteles.

Digestive gland cells (zymogen cells) are comparatively scarce. Their number does not exceed 12 per larva, most having about 8 (Fig. 17). They have a slender, gobletshaped cell body (Fig. 5), with the pointed base normally touching the mesolamella. The apical portion of the cell is filled with a large quantity of acidophilic secretory droplets. Characteristically, the nucleus contains a swollen nucleolus.

\section{Metamorphosis}

Within a period of $2.5 \mathrm{~h}$ to about $1 \mathrm{~d}$ after hatching, most of the planulae observed attached to a substratum and began to metamorphose. Based upon morphological and histological criteria, the transformation of the larva into a primary polyp can be subdivided into 9 stages. Metamorphosis is completed within 21-24 h.

Stag e 1: The larva attaches to the ground by its anterior (= aboral) pole and raises the hind body slowly until it stands free in an upright position. Its initial adherence is probably due to a sticky mucus secreted by the frontally-condensed mucous cells. 


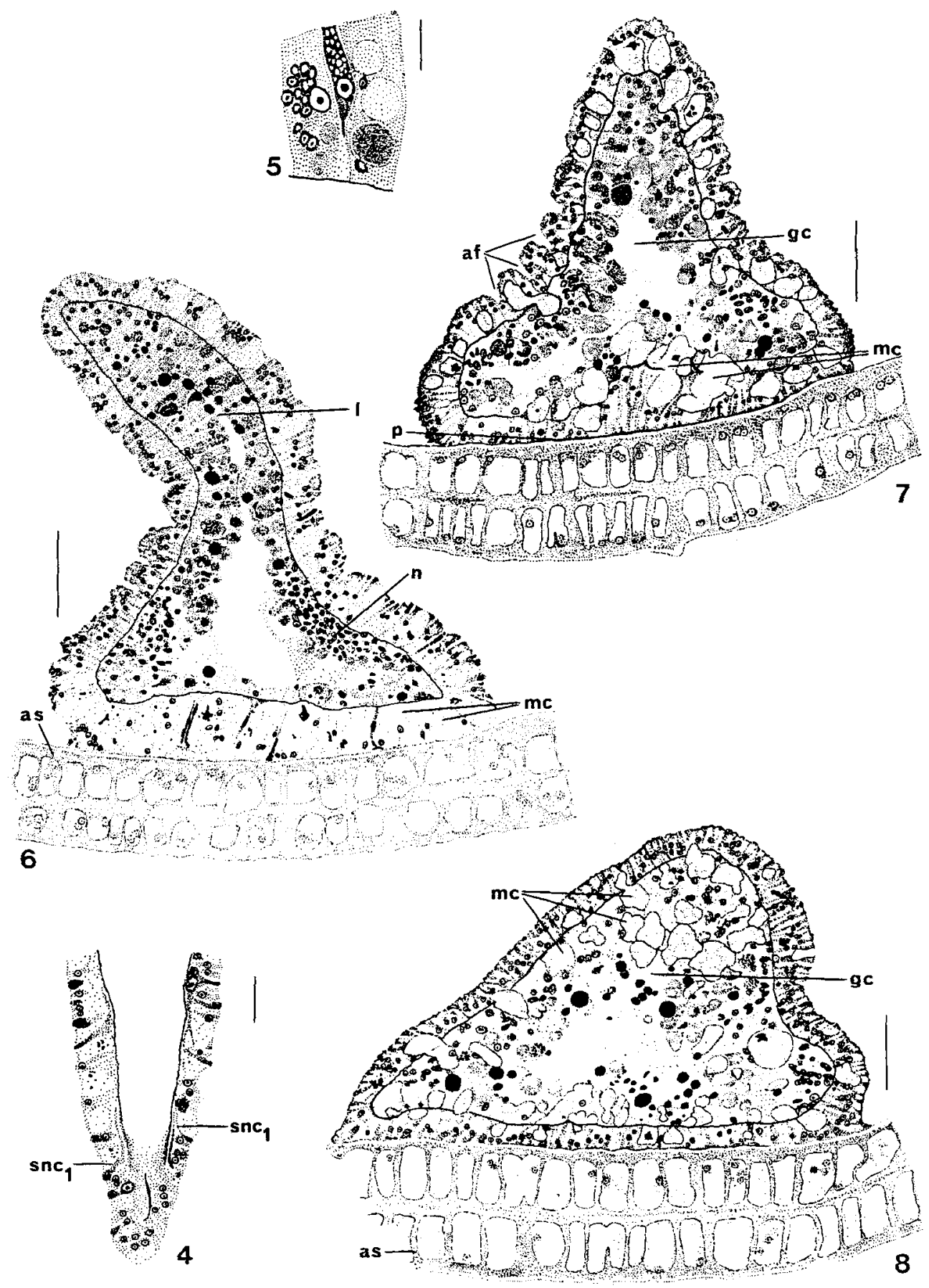

Figs 4-8. Eudendrium racemosum. 4. Oral pole of a planula (only ectodermal layer drawn); 5. Digestive gland cell between entodermal cells; 6 . Stage 1 of metamorphosis; 7 . Stage 2 (early phase); 8. Stage 2 (late phase). Scales: Fig. 4: $20 \mu \mathrm{m}$; Fig. 5: $10 \mu \mathrm{m}$; Figs 6-8: $50 \mu \mathrm{m}$ 
Subsequent permanent fixing to the substratum is by peridermal material secreted from the epitheliomuscular cells. Although a secretion was not directly visible under the light microscope, this conclusion was drawn because of the sudden loss of apical granula from the epitheliomuscular cells when they came to adhere to the substratum. The adhesion zone enlarges continuously from a central, spot-like region outwards until it covers a relatively wide, circular plane on the underlying surface (see Fig. 6).

The mucous cells exhibit an increased secretory activity during planula attachment, but they are never emptied completely. Those situated near the aboral pole become unavoidably enclosed between substratum, mesolamella, and the neighbouring epidermal cells (Fig. 6; mc). This results in the termination of mucus secretion. The small secretory and sensory-nervous cells located aborally become enclosed too, but the question of how their normal functions are affected by this event cannot yet be answered.

The entoderm is not directly involved in the attachment. However, it takes part in the changes in proportion of the larval body connected with settlement. Whereas the free planula is worm-like in shape, following settlement its anterior end swells considerably. This is caused by the progressive enlargement of the adhesive region. At this time, the icells, cnidoblasts, and premature cnidocytes move forward and come to lie in the entodermal wall of the thickened anterior portion of the body (Fig. 6 ; n). Simultaneously, the gastral cavity becomes broader at the adhesive end but almost disappears at the opposite one, except for some transiently persisting small lacunae (Fig. $6 ; 1$ ).

Stage 2: The following stage in development is characterized by the larva's gradual shortening in length. The body flattens and the enlargement of the aboral adhesive zone started in stage 1 continues (compare Fig. 7 with Fig. 8). A typical associated feature is the formation of annular folds or wrinkles running through the ectoderm (Fig. 7 ; af). They may result from strong contractions of the myofibrils of the epitheliomuscular cells.

At the beginning of stage 2 , a very thin periderm lamella becomes visible between the centre of the adhesive disk and the underlying surface (Fig. 7 ; p). Its location corresponds to the spot-like region that was the first to stick to the substratum during stage 1 . The peripheral zone of the adhering ectoderm includes at least a major part, if not all, of the granular ring zone that was described in the free-living planula.

During the flattening period, ectodermal mucous cells are found to cross the mesolamella and to migrate inwards to the entoderm. This movement typically starts in the adhesive region (Fig. $7 ; \mathrm{mc}$ ). A short time later the first mucous cells of the upper ectoderm also start to immigrate by forcing their basal ends through small openings in the mesolamella. After the foot is anchored between the bases of gastrodermal cells, it swells by the influx of cellular contents from the ectodermal side. Thus the volume still remaining in the ectoderm is progressively diminished. Figure 7 shows three mucous cells of the upper ectoderm in an early to middle state of their passage, and Figure 8 shows four at a middle to late stage.

When the mucous cells have intruded into the entoderm, they do not stay near the mesolamella but continue their centripetal movement. Probably due to the great number of immigrated cells, the volume of the inner layer increases, resulting in an increase in the epithelial thickness and, in parallel, a decrease of the volume of the central gastral cavity (Figs 7, 8; gc).

$\mathrm{Stage} \mathrm{3:} \mathrm{The} \mathrm{attached} \mathrm{larva} \mathrm{now} \mathrm{has} \mathrm{flattened} \mathrm{to} \mathrm{a} \mathrm{maximum} \mathrm{degree} \mathrm{(Fig.} \mathrm{9).} \mathrm{At}$ 
about the same time, the enlargement of the adhesive disk ceases. Thus, the formerly worm-like larval body is altered to a lens- or button-like shape, with the adhesive zone representing the aboral end of the planula.

The ectoderm is nearly free of mucous cells, and only the basal adhesive epithelium may still contain some late-immigrating cells (Fig. 9; mc). Those mucous cells that moved into the entoderm during stage 2 disappear from this tissue during stage 3 . At the same time, increasing amounts of acid mucopolysaccharides can be demonstrated in the gastral cavity by the use of alcian blue or azure II. Hence, it is highly conclusive that mucous cells are released into the gastric lumen following loss of their cellular boundaries.

Similar to the mucous cells, the small secretory and sensory-nervous cells described in the planula throughout the ectoderm are not present any longer. A more detailed information on their fate, however, could not be obtained.

While the migration of mucous cells from ectoderm to entoderm is almost completed, i-cells, cnidoblasts, and premature cnidocytes begin to cross the mesolamella in the opposite direction. The location of their passage is strictly confined to the base of the button-shaped organism, slightly above the adhesive region. Here, the three cell types lie condensed on the entodermal side in a ring structure parallel with the plane of the adhesive zone (Fig. 9; r). Subsequent to their entry into the ectoderm the i-cells, cnidoblasts, and premature cnidocytes move orally as well as aborally. However, they do not invade the basal adhesive epithelium. The premature cnidocytes spread over the upper ectoderm more rapidly than do the i-cells and cnidoblasts.

During stage 3, a new cell type is generally noticed in small numbers. It is found either located between the apices of the gastrodermal cells (Fig. $9 ; \mathrm{vc}_{1}$ ) or floating in the gastral cavity (Fig. 9; vc ${ }_{2}$ ). All cells of this type have a very large nucleus the diameter of which ranges from 5.5 up to $10.5 \mu \mathrm{m}$. The nucleus is surrounded by yolk belonging to type 2 (cf. section on "Hatching of planulae"). When the cell floats freely in the gastral lumen, the yolk develops an acidophilic granulation. Gradually the yolk becomes more and more reduced until there remains only a thin film surrounding the nucleus. Because of these characteristics, the described cell type is regarded as a vitellophagous cell that performs an accelerated yolk decomposition, compared with that of normal gastrodermal cells.

Stages 4 and 5: A blunt-ending column grows up from the centre of the flattened disk (Stage 4, Fig. 10). Following this, a slight constriction at the base of the column and a weak swelling of its distal part divide the body into 3 portions; the upper represents the future head (= hydranth), the middle the stem, and the lower the foot of the developing primary polyp (stage 5 , Fig. 11).

The composition of the two germ layers differs from that of the planula due to the preceding outwandering of several cell types from their original epithelium (see description of stages 2 and 3). The ectoderm now consists of epitheliomuscular cells, i-cells, cnidoblasts, and premature cnidocytes. The entoderm contains gastrodermal cells, digestive gland cells, and a small number of remaining premature cnidocytes (Figs 10, 11; c ent).

At stage 4, the epitheliomuscular cells of the upper side of the basal disk (foot) produce a thin peridermal covering (Fig. 10; p). The secretion of periderm is continued over the developing head during stage 5 (Fig. 11; p). Thus the organism is completely surrounded by an acellular peridermal layer at the end of stage 5 . 

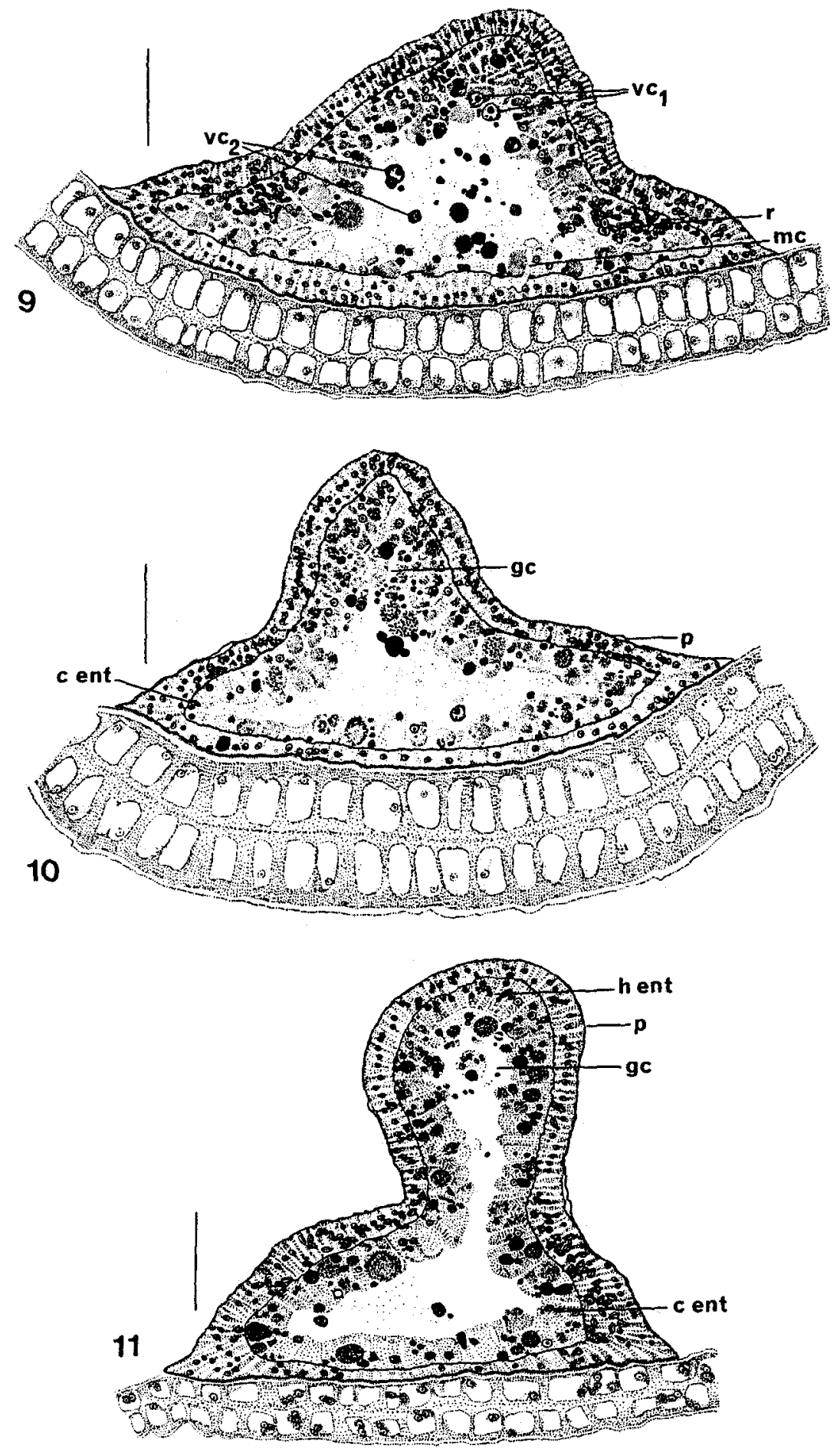

Figs 9-11. Eudendrium racemosum. 9. Stage 3 of metamorphosis; 10. Stage 4; 11. Stage 5. Scales: $50 \mu \mathrm{m}$ 
The oral projection of the gastral cavity widens considerably when the distal body portion swells to form the primordial head (compare Fig. 10 with Fig. 11; gc). Synchronously, a distinct entodermal differentiation at the top of the head marks the initial development of the hypostome (Fig. 11; h ent). The cells found here are lowered, closelypacked and cylindrical with small nuclei. Their plasma contains only very small amounts of yolk, in contrast to other gastrodermal cells.

St a ge 6: This stage comprises two morphogenetic events: (1) The formation of an annular constriction, separating an oral cap, the future hypostome, from the lower hydranth body (Fig. 12; cs), and (2) the appearance of several vertical (i.e. longitudinal) furrows that run through the hydranth wall and divide it into 6 or 7 tentacle buds. The latter are hardly visible in longitudinal section but are well shown in transverse ones (Fig. 13 ; tb). Figure 13 shows that both germ layers are involved in the formation of even the youngest buds observed. Centrally, the buds consist of entodermal cells with strongly basophilic cytoplasm and low yolk content (Fig. $13_{i} \mathrm{bc}$ ). A short projection of the gastral cavity runs into the base of every tentacle bud (Fig. 13; tgc).

The distribution of i-cells, cnidoblasts, and premature cnidocytes is not significantly altered since they moved into the ectodermal layer. Most of the i-cells and cnidoblasts are found crowded in the upper basal disk, while premature cnidocytes are intermingled with them as well as irregularly dispersed throughout the stem and the hydranth ectoderm.

The differentiated entoderm of the developing hypostome has by this time enlarged (Fig. 12; h ent). Its boundary with the typical yolk-containing gastrodermal cells of the lower hydranth body corresponds to the external groove separating the hypostomal cap from the tentacular region. Due to the process of constriction, the gastral cavity becomes parted into hypostomal and stomach portions. The junction canal between them is still relatively wide at the developmental stage illustrated in Figure 12 (jc).

Stage 7 : Following the formation of the circle of 6 or 7 primordial tentacle buds the bud tips start to grow in an oral direction. New buds originate one by one from the same circle, raising the tentacle number to 9-13 at stage 7 (Fig. 18). Synchronously, further constriction of the hypostomal base occurs.

The decomposition of yolk now becomes drastically enhanced in the gastral epithelium of the basal disk, stem, and hydranth body. Most of the cells show a significant decrease in the quantity of yolk granules, apparently accompanied by a slight increase in the amount of cytoplasm. As a result, the gastrodermal cells shrink a little (Fig. $14 ; \mathrm{gdc}$ ).

Two exceptions from this rule are generally noticed: (1) Between the numbers of cells shrinking in the described manner, a few remain in the characteristic embryonic state, that is with large cell bodies rich in yolk material, and are therefore called "reserve cells" (Fig. $14 ; \mathrm{rc}_{1}$ ). (2) Similar cells, though grouped instead of single, surround the junction canal that links the hypostomal portion of the gastral cavity with the stomach (Fig. 14; $\left.\mathrm{rc}_{2}\right)$.

St a ge 8: Morphologically, stage 8 is characterized by the further outgrowth of the embryonic tentacles and the continuous formation of new ones. Their total number reaches 11-17 (Fig. 18). In addition, the base of the hypostome now becomes fully constricted, thus separating the oral (hypostomal) from the aboral (stomachic) gastral lumen by a tightly-closing pharynx (Fig. 15; ph).

The peridermal sheet, wholly covering the ectoderm of the metamorphosing animal 


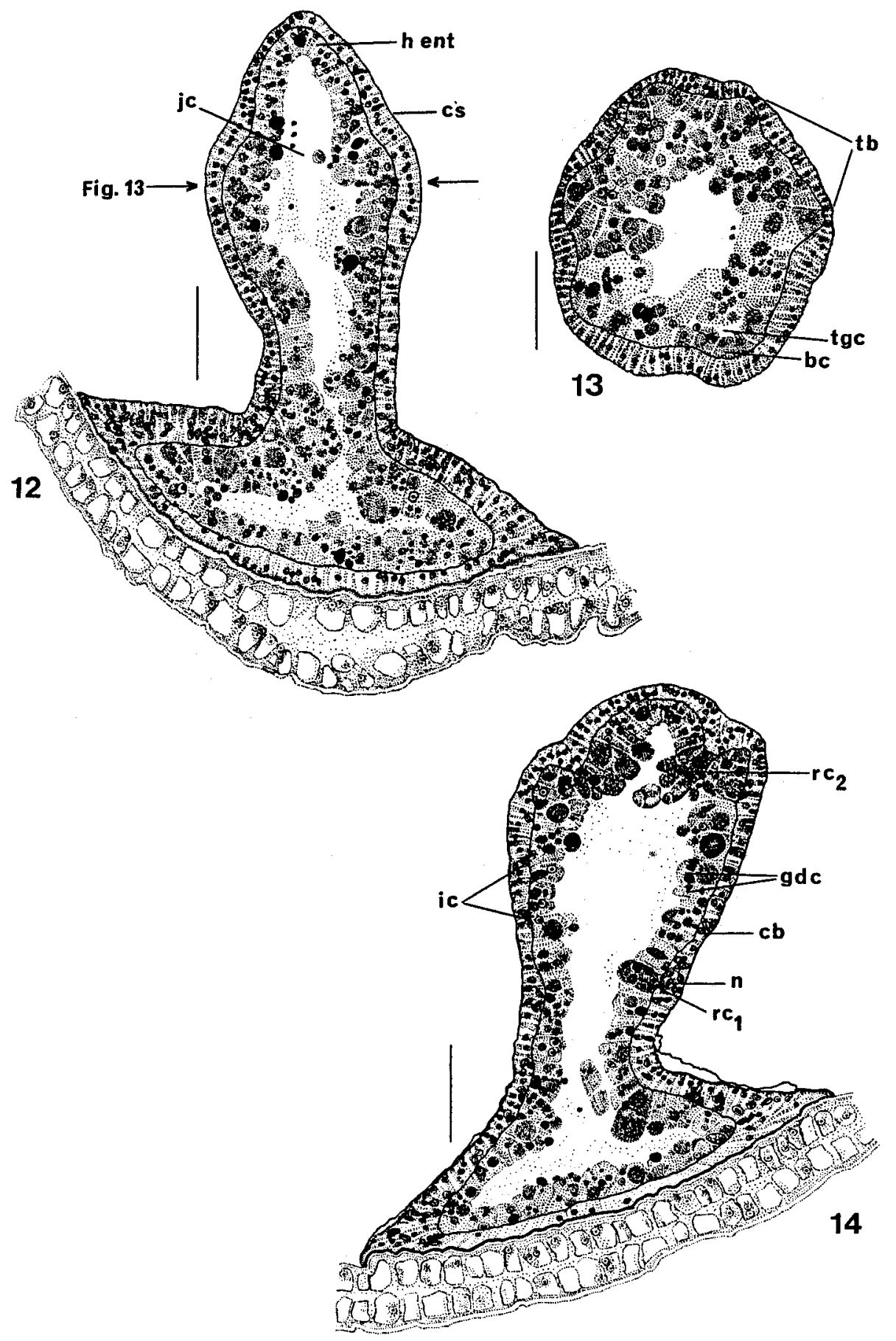

Figs 12-14. Eudendrium racemosum. 12. Stage 6 of metamorphosis; 13. Transversal section through the tentacle budding region at the level indicated by arrows in Fig. $12 ; 14$. Stage 7 . Note peridermal covering over the head. Scales: $50 \mu \mathrm{m}$ 


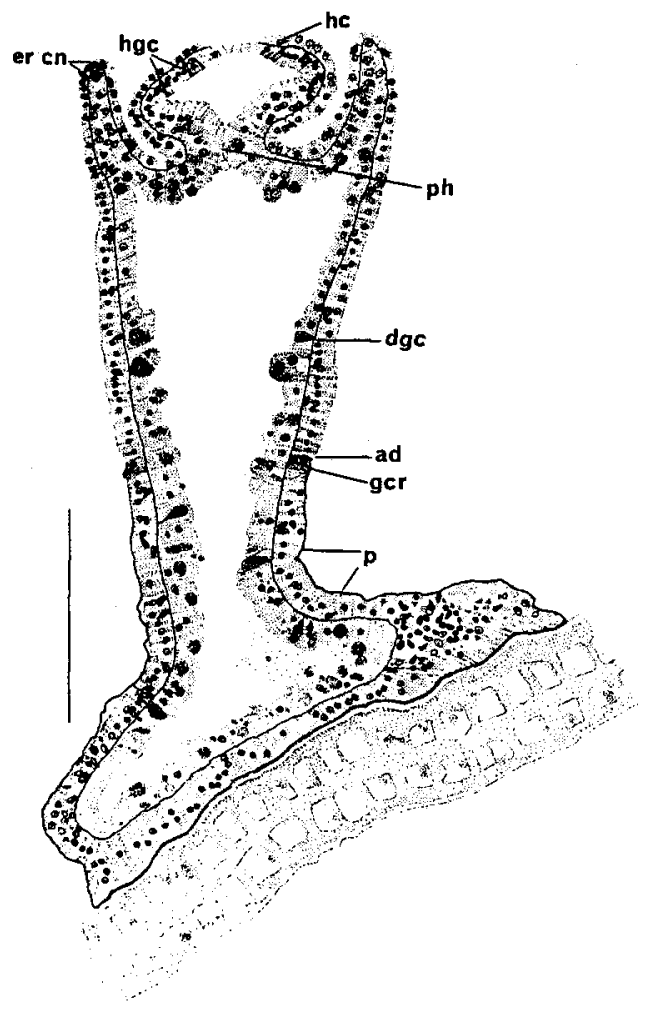

Fig. 15. Eudendrium racemosum. Stage 8 of metamorphosis. Scale: $100 \mu \mathrm{m}$

since stage 5 , becomes lost over the hypostome, the tentacles, and most of the body wall of the hydranth. It persists over the hydranth base, the stem, and the foot (Fig. 15; p). The location of the upper margin of the periderm tube always corresponds to a ring of differentiating ectodermal cells that are conspicuous by their increasing plasmatic basophily, forming a gland cell ring (Fig. 15; gCr). Immediately above this structure, a very slight annular depression runs around the surface of the ectoderm (Fig. 15; ad).

Premature cnidocytes are now more frequently found in the tentacular ectoderm than in the preceding stages. Most of the cnidae lie with their longitudinal axes almost parallel with the mesolamella, probably indicating that these cells have not yet finished migration. Others have erected their capsule so that its pointed end pierces the epithelial surface (Fig. 15; er $\mathrm{cn}$ ). These are thought to be the first ones to acquire a mature, i.e. dischargable, condition. Those cnidocytes that occasionally migrate into the hypostomal ectoderm (Fig. 15; hc) or that are distributed in the hydranth wall have never been observed to bring their capsules to an erected position.

Figure 15 shows a developing polyp in which the mouth opening is just about to be formed. The ectodermal cells are withdrawn from the top of the bulb-shaped hypostome, while the entodermal layer still acts as a flattened bridge over the prospective.opening. The question of whether or how the mesolamella is locally affected at this stage of development could not be definitely answered. 
Near the developing mouth, a new cell type differentiates in the entoderm, the hypostomal granula cell (Fig. 15; hgc). Its cylindrical to cone-shaped body resembles that of the typical supporting cells of the hypostomal entoderm, but it differs in containing masses of minute acidophilic granules. These are mainly concentrated in the apical half to two-thirds of the cell body.

Another sort of granula cell, the digestive gland cell, has already been recognized in the planula entoderm (see section on "Free planulae"). This cell type is considerably larger than the hypostomal one. Moreover, it is present during the whole of metamorphosis, although it does not exceed a mean number of about 8-10 per animal until stage 7 (Fig. 17). Beginning with stage 7 the frequency of digestive gland cells in the entoderm increases, reaching 14-21 per animal at stage 8. Most of them are situated in the entoderm of the basal disk and the stem, but a few have also been identified in the stomach (Fig. 15; dgc). This is remarkable because in full-grown primary polyps (see below), as well as in asexually born stock hydranths (Mergner, 1957), no digestive gland cells are found in the stomach.

Stage 9: Metamorphosis is completed by a continuation of the developmental trends that started in the preceding stages. The tentacles grow to their final length of about three or four times that of stage 8 , while the formation of new buds ceases. The full number of tentacles in primary polyps varies from 13 to 19 (Fig. 18). Even before the tentacles reach their final length, the mouth breaks open at the oral pole of the hypostome, apparently by rupture of the entodermal bridge described in stage 8 . In undisturbed living polyps, the lips are normally closed tight; but when the polyp is excited by food, or is influenced by fixative solution, the hypostome opens wide and assumes the shape of a calyx.

The tentacular ectoderm consists of flattened epitheliomuscular cells and irregularly distributed cnidocytes, most of which have erected their capsules in a position ready for firing (Fig. 16; er $\mathrm{cn}$ ). All cnidocytes can be identified as microbasic euryteles by the presence of a typical acidophilic stylet lying slightly oblique to the longitudinal axis of the capsule. At high magnifications, the small, lens-shaped nucleus of a cnidocyte can be seen lying near to or in close contact with the capsule at its blunt end.

The differentiation of the gland cell ring (Fig. 16; gcr) surrounding the base of the hydranth is advanced, as demonstrated by a further increase of the cytoplasmatic stainability with basic dyes. The ring has an oral-aboral measurement of only one or two cell dimensions. Orally, it is separated from the neighbouring ectodermal cells by a ringfurrow that deeply intersects the epithelium so that the mesolamella is generally laid free over a small distance (Fig. 16; rf).

A very delicate film of periderm covers the gland cell ring and continues aborally over the base of the hydranth, the constricted "neck" region (Fig. 16; nc), the stem, and the foot. Here it becomes gradually thicker, with a single abrupt increase in thickness between neck to stem. In living primary polyps, the stem was observed to grow rather quickly. Considering its morphology, it can be derived that periderm is primarily formed by the cells of the gland ring, then moved aborally, while new material is secreted from the following ectodermal cells and attached to the inner surface of the tube. In support of this, acidophilic granules that might represent precursory secretion material are often found near the apices of the ectodermal cells of the hydranth base, the neck, and the upper stem (Fig. 16; g). 


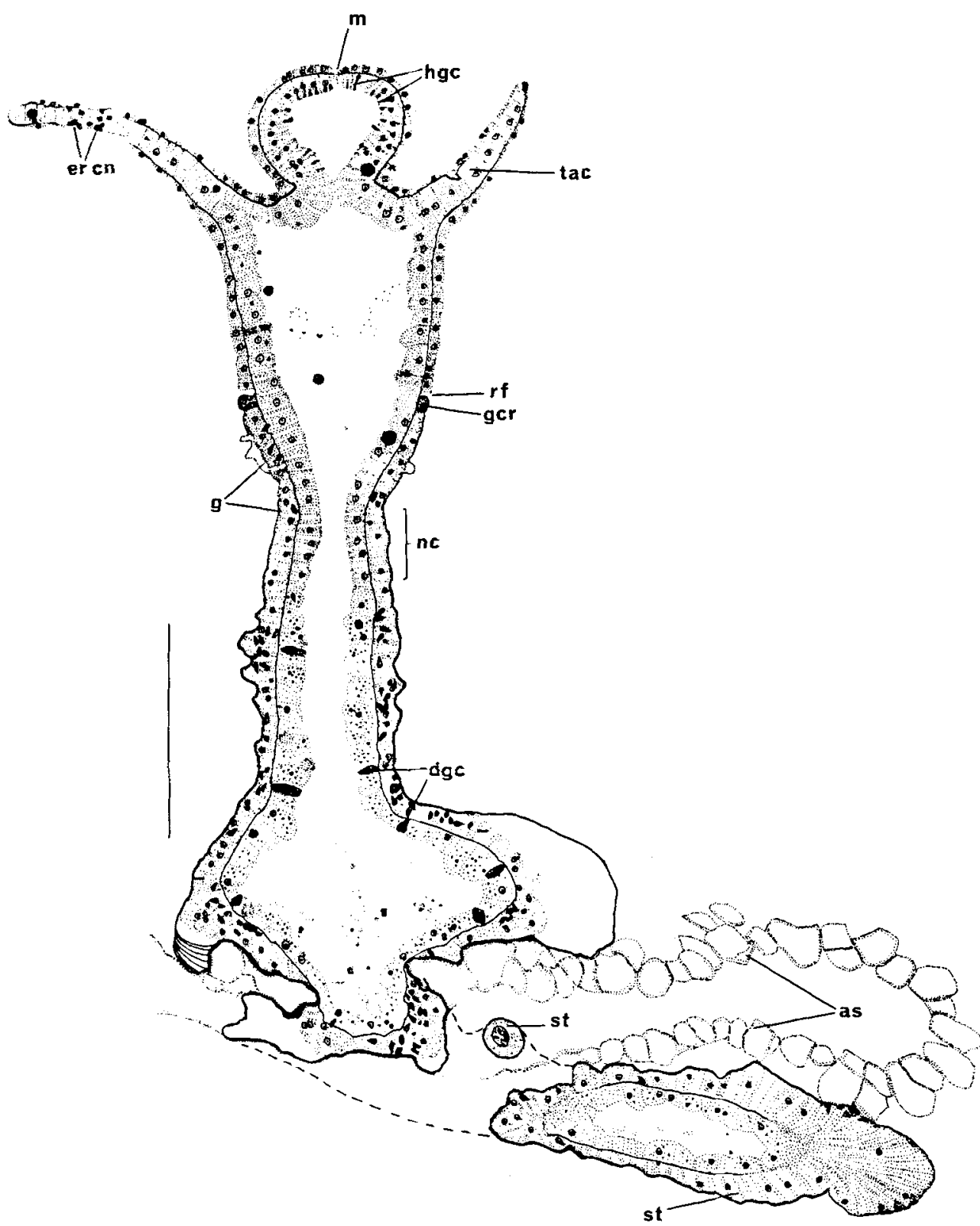

Fig. 16. Eudendrium racemosum. Stage 9. Fully developed primary polyp. Scale: $100 \mu \mathrm{m}$ 

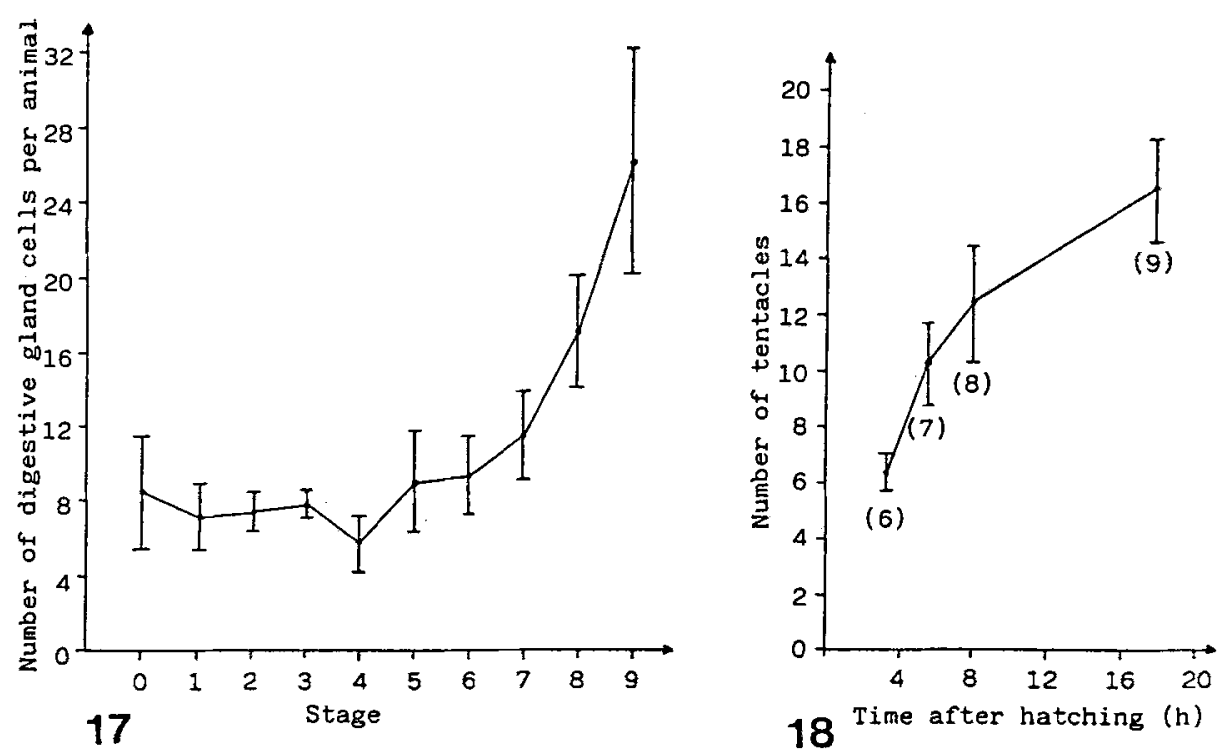

Figs 17-18. Eudendrium racemosum. 17. Increase in number of digestive gland cells during metamorphosis. Bars show standard deviations. 18. Successive numbers of tentacles during stages 6 to 9 . Numbers in brackets give the respective stages. Bars show standard deviations

Differentiation of the entoderm has proceeded in a manner that enables the organism to change from lecithotrophic to planktotrophic nutrition. The hypostomal granula cells (Fig. 16; hgc) have increased in number and are more widely distributed over the hypostomal entoderm than in stage 8 . The intracellular storage of the granules towards the cell apex probably indicates their secretory nature. The function of the secreted substance may be digestive (cf. Bouillon, 1966, in Halocordyle disticha) or adhesive (ensuring the intake of food organisms caught by the tentacles), or both.

The gastrodermal cells of the stomach and neck are almost uniform in shape but decrease in size towards the latter. Yolk particles are scarce in the stomach cells and absent in the neck region. Digestive gland cells are absent from both regions. At the tentacle bases the gastroderm builds a funnel-shaped, blind-ending duct that is followed by a row of large tentacular axial cells (Fig. 16; tac). Each possesses a centrally lying nucleus and a highly vacuolated cytoplasm.

The entoderm of the stem and foot differs from that of the stomach and neck in two respects: (1) digestive gland cells are present in high numbers; their abundance has even increased since stage 8 (see Fig. 17); (2) the entodermal cells lining the gastral cavity of stem and foot have by now developed intracellular vesicles. These stain weakly with acidic dyes and are distributed without any preferential location in the cytoplasm. Whether they represent a particular type of secretory vesicles or might be involved in the intracellular digestion of phagocytozed food particles cannot be decided at present. 


\section{DISCUSSION}

The general body organization of the planula of Eudendrium racemosum and its metamorphosis into the primary polyp is consistent with the majority of facts known from several species from other hydroid families. For example, the initial differentiation of $i$ cells, cnidoblasts, and premature cnidocytes in the larval entoderm has been confirmed to be common to all hydroid species that pass through a planula stage in their development (Harm, 1903; Mergner, 1957, 1971; Weiler-Stolt, 1960; Bénard-Boirard, 1962; Cowden, 1965; van de Vyver, 1964, 1967; Bodo \& Bouillon, 1968; Summers \& Haynes, 1969; Martin \& Thomas, 1977; Martin et al., 1983; Martin \& Archer, 1986a). In several species, a few premature cnidocytes penetrate the mesolamella as early as the planula stage and are erected in the ectoderm, for example in Hydractinia echinata (see van de Vyver, 1964), Cordylophora caspia (see van de Vyver, 1967), and Phialidium hemisphaericum (see Bodo \& Bouillon, 1968). These are said either to have a defensive function or to play a role in the larva's attachment to the substratum, the latter being demonstrated in Hydractinia echinata alone (Chia \& Bickell, 1978). Premature cnidocytes were occasionally found in the ectoderm of planulae of Eudendrium racemosum too, but always in very low numbers and never erected in a position for discharge. In all of the investigated species, a mass emigration of $\mathrm{i}$-cells, cnidoblasts, and premature cnidocytes occurs in connection with metamorphosis.

A mucus-secreting cell type occurs in the ectodermal layer of $E$. racemosum and in all other hydroid planulae so far examined. Secretion certainly facilitates settlement at the end of the larval period, due to the stickiness of the liberated mucus (Wasserthal \& Wasserthal, 1973).

A second type of secretory cell has been demonstrated in the larval ectoderm of a few species, namely Phialidium hemisphaericum, Obelia sp.,' Sarsia eximia (see Bodo \& Bouillon, 1968), and Coryne muscoides (see van de Vyver, 1967). It was named "cellule glandulaire sphéruleuse ectodermique". Cells with similar morphology, distribution, andacidophilic granules, were described as "kleine sekretorische Zellen" (small secretory cells) in Eudendrium armatum (see Wasserthal \& Wasserthal, 1973), and appear to be homologous with those found here in E. racemosum. It should be emphasized, however, that another group of granula-containing cells has been discovered in the planula of $E$. racemosum, the so-called sensory-nervous cells (Mergner, 1957). They are morphologically different from the above-mentioned secretory cells in possessing one or more long, sometimes ramified plasma processes running from the cell body into the lateral or apical interstitium. In view of the similarity between the two cell types in question it cannot be definitely decided whether they are truly distinct or not. In the latter case, all of them might be representatives of a neurosecretory cell that occurs in diverse morphological forms over the ectoderm. In fact, sensory as well as nervous cells with conspicuous neurosecretory granules have frequently been recognized in recent electron microscopic investigations of hydroid planulae (Martin \& Thomas, 1980, 1981b; Martin et al., 1983; Weis et al., 1985; Thomas et al., 1987).

Contrasting opinions are debated in the literature concerning the fate of ectodermal mucous cells during metamorphosis. In many species, the mucous cells are reported to be completely emptied within a few minutes after attachment (Bonner, 1955; van de Vyver, 1964, 1967, 1968a, b; van de Vyver \& Bouillon, 1969; Bodo \& Bouillon, 1968; Korn, 1966). 
Van de Vyver (1964) reported that in the planulae of Hydractinia echinata the rudiments of mucous cell bodies then degenerate in the ectoderm. Examining settlement and metamorphosis in the same species by use of electron microscopy, Weis \& Buss (1987) also found that mucous cells display an increased secretory activity during attachment but then disappear from the ectoderm by moving across the mesolamella into the entoderm. Here they undergo lysis, and numerous large mucous vesicles can be observed floating in the gastral cavity. The results obtained in the present study on E. racemosum clearly correspond with the last-mentioned view. Beginning at stage 2 , first the mucous cells of the basal adhesive region penetrate the mesolamella and immigrate into the entoderm, followed by those of the upper ectoderm. This movement comes to an end during stage 3 . Subsequently, increasing amounts of mucus can be detected histochemically within the gastral lumen. Hence, it seems highly probable that valuable organic matter is "recycled" by way of digestion. Future investigations must show whether $E$. racemosum and $H$. echinata are exceptional in this respect or if the process of mucous cell immigration has so far been overlooked in other species.

Subsequent to the immigration of mucous cells, masses of $\mathrm{i}$-cells, cnidoblasts, and premature cnidocytes migrate from the entoderm to the ectoderm. The role of ectodermal i-cells in metamorphosis is not clear. Beside their differentiation into cnidoblasts, WeilerStolt (1960) concluded from light microscopic observations on Eleutheria dichotoma that numerous i-cells participated in the formation of the hypostome and the tentacles. This finding is not confirmed by the present results from $E$. racemosum. From stage 3 onwards, $\mathrm{i}$-cells are abundant only in the ectoderm of the upper basal disk and of the developing stem, and are rarely present in the hydranth wall. None could be found in the tentacular and hypostomal regions. Hence, in E. racemosum, cells differentiating in the ectoderm or entoderm of the tentacles and the hypostome are believed to derive from normal epithelial cells. Examples are the tentacular axial cells and the hypostomal granula cells.

The sequence of tentacle budding during late metamorphosis is poorly known. Primary polyps with irregularly-dispersed tentacles, or with tentacles arranged in several whorls, develop the more oral tentacles first, then an equal number below the first whorl and so on. A typical sequence is 4, 8, 12 etc. Such a sequence has been described in Clava multicornis by Harm (1903) and Turritopsis nutricula by Brooks \& Rittenhouse (1906). Athecate hydranths with only one whorl form a primary set of tentacles that is doubled after a time. For example, the sequence 5, 10 was described in Stomotoca apicata (= Amphinema dinema) by Rittenhouse (1910) and 10, 20 in Eudendrium ramosum by Allman (1871). In contrast, the observations focused on this point in E. racemosum led to another result. Development starts with the budding of 6 or 7 tentacle anlages at stage 6 , followed irregularly by the formation of new buds between the bases of the outgrowing older tentacles. This proceeds gradually more slowly until stage 9 , when a number of 13-19 is reached. Although the number is higher in hydranths of an adult colony (about 28-35 after Wengler, 1974), the primary polyp does not bud further tentacles. Consequently, it must be suggested that tentacle formation again starts when the postmetamorphic polyp changes into a complex animal colony by asexual reproduction.

Neither is the primary polyp a true "adult" with regard to its cnidome. It has been pointed out that all cnidae on the tentacles - or, in a premature state, in the ectoderm of foot and stem - are exclusively microbasic euryteles. Likewise, this fact was also stated in the planula. However, a second type of cnidocyst occurs in colonial hydranths, namely 
the atrichous isorhiza (cf. Mergner, 1957, as "Glutinanten"; and Watson, 1985). Probably this second type performs functions for which there is no requirement in the primary polyp.

Acknowledgements. I wish to express my sincere thanks to Prof. Dr. H. Mergner for supervising the investigation and for his constructive criticism on the manuscript. I am indebted also to Dr. G. Bavestrello for his valuable help during my guest-stay at the Zoological Institute of the University of Genoa, Italy. For linguistic comments on the text, I thank Dr. P. F. S. Cornelius from the British Museum (Natural History), London.

\section{LITERATURE CITED}

Allman, G. J., 1871/72. A monograph of the gymnoblastic or tubularian hydroids. Part I: The Hydroida in general. Part II: The genera and species of the Gymnoblastea. Ray Society, London, $450 \mathrm{pp}$.

Bénard-Boirard, J., 1962. Développement embryonnaire de Podocoryne carnea (Sars) de Roscoff. Podocoryne carnea (Sars) forma exigua (Haeckel). - Cah. Biol. mar. 3, 137-156.

Bodo, F. \& Bouillon, J., 1968. Etude histologique du développement embryonnaire de quelques hydroméduses de Roscoff: Phialidium hemisphaericum (L.), Obelia sp. Peron \& Lesueur, Sarsia eximia (Allman), Podocoryne carnea (Sars), Gonionemus vertens Agassiz. - Cah. Biol. mar. 9, 69-104.

Bonner, J. T., 1955. A note concerning the distribution of polysaccharides in the early development of the hydromedusan Phialidium gregarium. - Biol. Bull. mar. biol. Lab., Woods Hole 108, 18-20.

Bouillon, J., 1966. Les cellules glandulaires des hydroides et des hydroméduses. Leur structure et la nature de leurs sécrétions. - Cah. Biol. mar. 7, 157-205.

Brooks, W. K. \& Rittenhouse, S., 1906. On Turritopsis nutricula (McCrady). - Proc. Boston Soc. nat. Hist. 33, 429-460.

Burck, H.-C., 1973. Histologische Technik. Thieme, Stuttgart, 205 pp.

Chayen, J., Bitensky, L. \& Butcher, R. G., 1975. Histochemie. Verl: Chemie, Weinheim, 228 pp.

Chia, F.-S. \& Bickell, L., 1978. Mechanisms of larval settlement and the induction of settlement and metamorphosis: a review. In: Settlement and metamorphosis of marine invertebrate larvae. Ed. by F.-S. Chia \& M. E. Rice. Elsevier, New York, 1-12.

Cowden, R. R., 1965. Cytochemical studies of embryonic development to metamorphosis in the gymnoblastic hydroid, Pennaria tiarella. - Acta Embryol. Morph. exp. 8, 221-231.

Hanisch, J., 1966. Spermienentwicklung von Eudendrium racemosum Cavolini. - Naturwissenschaften $53,587-588$.

Hanisch, J., 1970. Die Blastostyl- und Spermienentwicklung von Eudendrium racemosum Cavolini. - Zool. Jb. (Anat. Ontogenie Tiere) 87, 1-62.

Hargitt, C. W., 1900. A contribution to the natural history and development of Pennaria tiarella McCr. - Am. Nat. 34, 387-415.

Harm, K., 1903. Die Entwicklung von Clava squamata. - Z. wiss. Zool. 73, 115-165.

Hotchkiss, A. E., Martin, V. J. \& Apkarian, R. P., 1984. A scanning electron microscopic surface and cyrofracture study of development in the planulae of the hydrozoan, Pennaria tiarella. Scanning Electron Microsc. 2, 717-727.

Jha, R. K., 1965. The nerve elements in silver-stained preparations of Cordylophora. - Am. Zool. 5, $431-438$.

Korn, H., 1966. Zur ontogenetischen Differenzierung der Coelenteratengewebe (Polyp-Stadium) unter besonderer Berücksichtigung des Nervensystems. $-Z$. Morph. Ökol. Tiere 57, 1-118.

Kühn, A., 1913. Entwicklungsgeschichte und Verwandtschaftsbeziehungen der Hydrozoen. 1. Die Hydroiden. - Ergebn. Fortschr. Zool. 4, 1-284.

Martin, V. J. \& Archer, W. E., 1986a. Migration of interstitial cells and their derivatives in a hydrozoan planula. - Devl Biol. 116, 486-496.

Martin, V. J. \& Archer, W. E., 1986b. A scanning electron microscopic study of embryonic development of a marine hydrozoan. - Biol. Bull. mar. biol. Lab., Woods Hole 171, 116-125. 
Martin, V. J., Chia, F.-S. \& Koss, R., 1983. A fine structural study of metamorphosis of the hydrozoan Mitrocomella polydiademata. - J. Morph. 176, 261-287.

Martin, V. J. \& Thomas, M. B., 1977. A fine-structural study of embryonic and larval development in the gymnoblastic hydroid Pennaria tiarella., - Biol. Bull. mar. biol. Lab., Woods Hole 153, 198-218.

Martin, V. J. \& Thomas, M. B., 1980. Nerve elements in the planula of the hydrozoan Pennaria tiarella. - J. Morph. 166, 27-36.

Martin, V. J. \& Thomas, M. B., 1981a. Elimination of the interstitial cells in the planula larva of the marine hydrozoan Pennaria tiarella. - J. exp. Zool. 217, 303-323.

Martin, V. J. \& Thomas, M. B., 1981b. The origin of the nervous system in Pennaria tiarella, as revealed by treatment with colchicine. - Biol. Bull. mar. biol. Lab., Woods Hole 160, 303-310.

Mergner, H., 1957. Die Ei- und Embryonalentwicklung von Eudendrium racemosum Cavolini. Zool. Jb. (Anat. Ontogenie Tiere) 76, 63-164.

Mergner, H., 1971. Cnidaria. In: Experimental embryology of marine and freshwater invertebrates. Ed. by G. Reverberi. North-Holland Publ., Amsterdam, 1-84.

Morgenstern, P., 1901. Untersuchungen über die Entwicklung von Cordylophora lacustris Allman. Z. wiss. Zool. 70, 567-591.

Rittenhouse, S., 1910. The embryology of Stomotoca apicata. - J. exp. Zool. 9, 333-348.

Romeis, B., 1968. Mikroskopische Technik. Oldenbourg, München, $757 \mathrm{pp}$.

Summers, R. G. \& Haynes, J. F., 1969. The ontogeny of interstitial cells in Pennaria tiarella. J. Morph. 129, 81-87.

Thomas, M. B., Freeman, G. \& Martin, V. J., 1987. The embryonic origin of neurosensory cells and the role of nerve cells in metamorphosis in Phialidium gregarium (Cnidaria, Hydrozoa). - Int. J. Invertebr. Reprod. Dev. 11, 265-287.

Vyver, G. van de, 1964. Etude histologique du développement d'Hydractinia echinata (Flem.). Cah. Biol. mar. 5, 295-310.

Vyver, G. van de, 1967. Etude du développement embryonnaire des hydraires athécates (gymnoblastiques) à gonophores. 1. Formes à planula. - Archs Biol., Paris 78, 451-518.

Vyver, G. van de, 1968a. Etude du développement embryonnaire des hydraires athécates (gymnoblastiques) à gonophores. 2. Formes à actinulas. - Archs Biol., Paris 79, 327-363.

Vyver, G. van de, 1968b. Etude du développement embryonnaire des hydraires athécates (gymnoblastiques) à gonophores. 3. Discussion et conclusions générales. - Archs Biol., Paris 79, 365-379.

Vyver, G. van de \& Bouillon, J., 1969. Etude du développement embryonnaire et de l'histogenèse de Eleutheria dichotoma (De Quatrefages) (Anthoméduses Eleutheriidae). - Annls Embryol. Morphogen, 2, 317-327.

Wasserthal, W., 1973. Zur Ei- und Embryonalentwicklung des Hydroidpolypen Eudendrium armatum. - Helgoländer wiss. Meeresunters. 25, 93-125.

Wasserthal, L. T. \& Wasserthal, W., 1973. Ökologische Bedeutung der Schleimsekretion bei den Planula-Larven der Hydroidengattung Eudendrium. - Mar. Biol. 22, 341-345.

Watson, J. E., 1985. The genus Eudendrium (Hydrozoa: Hydroida) from Australia. - Proc. R. Soc. Vic. $97,179-221$.

Weiler-Stolt, B., 1960. Über die Bedeutung der interstitiellen Zellen für die Entwicklung und Fortpflanzung mariner Hydroiden. - Wilhelm Roux Arch. EntwMech. Org. 152, 398-455.

Weis, V. M. \& Buss, L. W., 1987. Ultrastructure of metamorphosis in Hydractinia echinata. - Postilla $199,1-20$.

Weis, V. M., Keene, D. R. \& Buss, L. W., 1985. Biology of hydractinid hydroids. 4. Ultrastructure of the planula of Hydractinia echinata. - Biol. Bull. mar. biol. Lab., Woods Hole 168, 403-418.

Wengler, B., 1974. Zur Systematik der Hydroidengattung Eudendrium Ehrenberg im Mittelmeer. Hausarb. Fachprüf. Lehramt an Gymnasien, Univ. Bochum, 162 pp. 